\title{
PENGARUH DESAIN PRODUK DAN HARGA TERHADAP KEPUTUSAN PEMBELIAN PADA TOKO BAHAGIA MEDAN
}

\author{
Azizah Hanum \\ Universitas Dharmawangsa \\ azizahhanum484@gmail.com
}

\begin{abstract}
Abstrak
Salah satu elemen bauran pemasaran adalah harga (price). Pada elemen ini dapat memberikan pedoman bagi dengan masalah harga produk. Toko Bahagia Medan memiliki perbedaan harga produk yang cukup tinggi dengan produk pesaing yang telah terkenal (top brand) sekitar 3-9\%. Konsumen lebih memilih untuk mengambil produk pesaing yang sudah terkenal dibanding produk Toko Bahagia. Elemen harga merupakan hal yang terpenting karena, tanpa adanya harga yang pasti terlebih dahulu merupakan hal yang sulit bagi perusahaan menetapkan kualitas produk, mengadakan promosi penjualan, dan mendistribusikannya.

Selain harga, penerapan desain produk yang baik dalam pemasaran dapat menarik minat konsumen yang berdampak positif pada perusahaan seperti keputusan pembelian yang berdampak pada peningkatan penjualan dan menciptakan citra yang baik bagi perusahaan. Jika digabungkan, harga dan desain produk merepresentasikan gabungan semua unsur dalam bauran pemasaran, yang memfasilitasi terjadinya pertukaran dengan menciptakan suatu arti yang disebarluaskan kepada pelanggan atau kliennya. Konsep dari desain produk ini bisa menjadi suatu kebijakan perusahaan ataupun pembenahan total dalam manajemen suatu perusahaan Desain produk selama ini dikenal sebagai aktivitas yang tidak terpisahkan dari dunia bisnis.
\end{abstract}

Keyword : Desain produk, Harga, Keputusan Pembelian. 


\section{PENDAHULUAN}

Penerapan teknologi informasi yang tepat akan dapat mempermudah dan meningkatkan kepuasan dari pemakainya. Selain itu penerapan teknologi informasi yang tepat dapat menurunkan biaya secara keseluruhan maupun berdampak pada peningkatan laba. Seiring dengan perkembangan teknologi informasi dan berbagai fasilitas aplikasinya serta semakin ketatnya persaingan maka perusahaan dituntut untuk dapat mengatur sistemnya agar dapat berlangsung secara efektif dan efisien. Dalam kegiatan produksi agar target produksi dapat tercapai dan tidak ada hambatan-hambatan yang dapat mengganggu kelancaran produksi, maka perlunya koordinasi yang baik antara bagian produksi dan bagian persediaan material, baik itu persediaan bahan baku, persediaan barang setengah jadi, atau persediaan barang pembantu. Bagian persediaan material harus dapat mengontrol atau mengatur persediaan agar tidak terjadi kekurangan atau kelebihan material yang terlalu banyak. Untuk mengatasi masalah ini maka setiap perusahaan membutuhkan suatu pengendalian persediaan bahan baku yang baik. Kegiatan pengendalian kebutuhan persediaan bahan baku yang digunakan harus dapat mengatur kelangsungan proses produksi di perusahaan.

Masalah yang dihadapi oleh Toko Bahagia Medan adalah kesulitan dalam menentukan unit produksi harus diproduksi pada periode mendatang, sehingga dalam perencanaan produksinya mengalami gangguan terutama dalam hal pemesanan bahan baku dan kapan perlu dilakukan pemesanan kembali. Akibat dari kesalahan perencanaan produksi tersebut menyebabkan terjadinya keterlambatan dalam produksi bahkan menyebabkan terhentinya aktifitas produksi. Secara teknis Toko Bahagia tidak mengalami kesulitan dalam kapasitas produksi karena seluruh kapasitas produksi dipakai secara maksimal. Sehingga perumusan masalah dalam skripsi adalah bagaimana memprediksi permintaan produk di periode yang akan datang dan merencanakan komponen atau bahan baku untuk produk kloset yang merupakan salah satu produk utama dari Toko Bahagia Medan

\section{KAJIAN PUSTAKA}

Desain produk adalah totalitas fitur yang mempengaruhi tampilan, rasa, dan fungsi produk berdasarkan kebutuhan pelanggan.

Harga adalah salah satu elemen bauran pemasaran yang menghasilkan pendapatan, elemen lain menghasilkan biaya.

Keputusan pembelian adalah beberapa tahapan yang dilakukan oleh konsumen sebelum melakukan keputusan pembelian suatu produk. 


\section{METODE PENELITIAN}

\section{Lokasi Penelitian}

Penelitian berlokasi di Toko Bahagia Medan Jalan Gelas, Komplek Topan Indah Permai No 1 Medan. Waktu Penelitian dilakukan dari Bulan April sampai dengan Juli 2019.

\section{Populasi dan Sampel}

Populasi yang akan digunakan dalam penelitian ini adalah toko yang menjadi pelanggan pada Toko Bahagia Medan sebanyak 127 responden. Dalam penelitian ini penulis mempersempit populasi yaitu jumlah pelanggan Toko Bahagia Medan sebanyak 127 responden dengan menghitung ukuran sampel yang dilakukan dengan menggunakan teknik Slovin. Sehingga sampel penelitian ini sebanyak 96 responden.

\section{Variabel dan Defenisi Operasional}

\section{Variabel Penelitian}

Variabel yang akan dianalisis dalam penelitian ini terdiri atas :

a) Variabel Bebas $\left(X_{1}\right)$ yaitu desain produk

b) Variabel Bebas $\left(X_{2}\right)$ yaitu harga

Variabel Terikat (Y) yaitu keputusan pembelian.

\section{DISCUSSION}

\section{Metode Persamaan Regresi Berganda}

Persamaan regresi berganda secara umum adalah:

$\mathrm{Y}=4,354+0,446 \mathrm{X} 1+0,298 \mathrm{X} 2+\mathrm{e}$

\begin{tabular}{|c|c|c|c|c|c|c|c|c|}
\hline \multicolumn{9}{|c|}{ Coefficients $^{2}$} \\
\hline \multirow{2}{*}{\multicolumn{2}{|c|}{ Model }} & \multicolumn{2}{|c|}{$\begin{array}{c}\text { Unstandardized } \\
\text { Coefficients }\end{array}$} & \multirow{2}{*}{$\begin{array}{c}\begin{array}{c}\text { Standardized } \\
\text { Coefficients }\end{array} \\
\text { Beta }\end{array}$} & \multirow[t]{2}{*}{$\mathrm{t}$} & \multirow[t]{2}{*}{ Sig. } & \multicolumn{2}{|c|}{$\begin{array}{l}\text { Collinearity } \\
\text { Statistics }\end{array}$} \\
\hline & & $\mathrm{B}$ & $\begin{array}{l}\text { Std. } \\
\text { Eror }\end{array}$ & & & & \begin{tabular}{|c|}
$\begin{array}{c}\text { Toleran } \\
\text { ce }\end{array}$ \\
\end{tabular} & VIF \\
\hline \multirow[t]{3}{*}{1} & (Constant) & 4.354 & 1.216 & & 3.581 & .001 & & \\
\hline & $\begin{array}{l}\text { DESAIN } \\
\text { PRODUK }\end{array}$ & .446 & .069 & .506 & 6.492 & .000 & .893 & 1.119 \\
\hline & HARGA & .298 & .066 & .350 & 4.484 & .000 & .893 & 1.119 \\
\hline
\end{tabular}

Koefisien 0,446 menunjukkan bahwa jika variabel desain produk ditingkatkan satu satuan maka dapat diikuti peningkatan variabel keputusan pembelian sebesar $44 \%$. 
Koefisien 0,298 menunjukkan bahwa jika variabel harga ditingkatkan sebesar satu satuan maka dapat diikuti oleh peningkatan variabel keputusan pembelian sebesar $29 \%$.

\section{Koefisien Determinasi $\left(\mathbf{R}^{2}\right)$}

\begin{tabular}{|l|c|r|r|r|}
\hline \multicolumn{5}{|c|}{ Model Summary $^{\mathrm{b}}$} \\
\hline Model & $\mathrm{R}$ & $\begin{array}{c}\mathrm{R} \\
\text { Square }\end{array}$ & $\begin{array}{c}\text { Adjusted R } \\
\text { Square }\end{array}$ & $\begin{array}{r}\text { Std. Error of } \\
\text { the Estimate }\end{array}$ \\
\hline 1 & $.703^{\mathrm{a}}$ & .494 & .484 & 1.797 \\
\hline \multicolumn{5}{|r|}{ a. Predictors: (Constant), HARGA, DESAIN PRODUK } \\
\hline \multicolumn{4}{|l}{ b. Dependent Variable: KEPUTUSAN PEMBELIAN } \\
\hline
\end{tabular}

Nilai R Square $=0,494$ berarti hubungan antara variabel desain produk dan harga sebesar 49,4\%. Artinya hubungan yang erat antar variabel. Angka Adjusted R Square sebesar 0,494 berarti 49,4\% keputusan pembelian dijelaskan oleh variabel desain produk dan harga. Sedangkan 50,6\% dapat dijelaskan variabel lain yang tidak diteliti dalam penelitian ini.

\section{Pengujian Hipotesis}

\section{Pengujian Hipotesis Secara Simultan Menggunakan Uji F}

Hasil uji signifikansi simultan dapat dilihat tabel berikut :

\begin{tabular}{|c|c|c|c|c|c|c|}
\hline \multicolumn{7}{|c|}{ ANOVA $^{b}$} \\
\hline \multicolumn{2}{|c|}{ Model } & Sum of & df & Mean & F & Sig. \\
\hline \multirow[t]{3}{*}{1} & Regression & 293.591 & 2 & 146.795 & 45.470 & $.000^{\mathrm{s}}$ \\
\hline & Residual & 300.243 & 93 & 3.228 & & \\
\hline & Total & 593.833 & 95 & & & \\
\hline \multicolumn{7}{|c|}{ a. Predictors: (Constant), HARGA, DESAIN PRODUK } \\
\hline
\end{tabular}

Berdasarkan tabel diatas nilai $F_{\text {hitung }}$ adalah 45,470 $>F_{\text {tabel }}$ 3,09 dengan tingkat signifikan 0,00. Sedangkan tingkat kepercayaan $(\mathrm{a}=0,05)$. Maka terdapat pengaruh yang simultan antara desain produk dan harga terhadap keputusan pembelian.

\section{Pengujian Hipotesis secara Parsial Menggunakan Uji t}

\section{a. Pengaruh $\mathrm{X}_{1}$ terhadap $\mathrm{Y}$}

Variabel desain produk memiliki nilai $t_{\text {hitung }} 6,492>t_{\text {tabel }} 1,663$. Ini berarti H1 ditolak sehingga dapat disimpulkan bahwa variabel desain produk berpengaruh terhadap keputusan pembelian pada Toko Bahagia Medan.

\section{b. Pengaruh $\mathrm{X}_{2}$ terhadap $\mathrm{Y}$}

Variabel harga memiliki nilai thitung 4,484 > tabel 1,663. Ini berarti $\mathrm{H} 1$ ditolak sehingga dapat disimpulkan bahwa variabel desain produk berpengaruh terhadap keputusan pembelian pada Toko Bahagia Medan 


\section{KESIMPULAN}

Berdasarkan hasil analisis dan pembahasan yang telah diuraikan sebelumnya, maka dapat ditarik beberapa kesimpulan dari keseluruhan hasil penelitian yaitu sebagai berikut :

1. Variabel desain produk dan harga berpengaruh secara simultan terhadap keputusan pembelian.

Variabel desain produk merupakan variabel yang paling dominan mempengaruhi keputusan pembelian..

\section{REFERENCES}

Alma, Buchari. 2013. Manajemen Pemasaran dan Pemasaran Jasa. Bandung: Alfabeta.

Ghozali, Imam. 2013. Aplikasi Analisis Multivariat dengan Program SPSS 19. Cetakan Kelima. Semarang: Badan Penerbit Universitas Diponegoro.

Kotler, Philip dan Gary Armstrong. 2008. Prinsip-prinsip Pemasaran. Edisi. 12. Jilid 1. Jakarta: Erlangga

dan Kevin Lane Keller. 2012. Prinsip-Prinsip Pemasaran, Jilid Satu, Edisi Ketigabelas Jakarta: Erlangga.

Shinta, Agustina. 2011. Manajemen Pemasaran. Malang: Universitas Brawijaya: Press.

Suharno. 2010. Marketing in Practice. edisi pertama, penerbit Graha Ilmu, Yogyakarta.

Supranto, J dan Limakrisna. 2011. Perilaku Konsumen dan Strategi Pemasaran

Untuk Memenangkan Persaingan Bisnis. Jakarta: Mitra Wacana Media. 